УДК 94 (477) «1939/1945»

ТРОФИМОВИЧ Л.В.

http://orcid.org/0000-0003-2393-9128

СУХИХ А.Ю.

https://orcid.org/0000-0002-5787-2841

https://doi.org/10.33577/2313-5603.32.2019.245-251

\title{
НЕПРОГОВОРЕНА ДО КІНЦЯ ДРУГА СВІТОВА ВІЙНА
}

Війна. Грані / редкол.: Л. Легасова (кер. проекту) та ін. Київ: Національний музей історії України у Другій світовій війні. Меморіальний комплекс, 2018. 220 c.

Друга світова війна як найтрагічніший і найкривавіший період історії людства потребує подальшого глибокого осмислення, вивчення та прискіпливої уваги, оскільки їі наслідки відчуваються дотепер, а окремі сторінки продовжують усе ще залишатися основою для спекуляцій, спрямованих на роз'єднання українського соціуму.

Тривалий час Друга світова війна розглядалася через призму діяльності державних структур, військових формувань і армій, де окрема особистість і ї доля опинялися за лаштунками. Однак саме роль людини у війні залишається недостатньо промовленою. Долі мільйонів вирішувалися у горнилі жорстокості та смерті, де питання виживання поставало на перше місце, відкидаючи на задній план життєві цілі побудувати щасливе майбутнє.

Рецензована книга являє собою збірник матеріалів, у якому представлені фото унікальних предметів, документів та експонатів, що зберігаються у Національному музеї історії України у Другій світовій війні (далі - НМІУДСВ).

Світ речей, які знайшли своє місце на сторінках видання, дають можливість простежити грані Другої світової війни, що від ображають головні їі фактори та особливості, що вплинули на життя людей, які опинилися в окупації, воювали у складі Червоної Армії (далі - ЧА) на фронті, евакуювались у радянський тил, перенесли

Трофимович Лілія Володимирівна, кандидат історичних наук, доцент, професор кафедри гуманітарних наук, Національна академія сухопутних військ імені гетьмана Петра Сагайдачного, м. Львів.

Сухих Андрій Юрійович, здобувач кафедри історії імені М.П. Ковальського Національного університету «Острозька академія», м. Острог.

(C) Трохимович Л.В., Сухих А.Ю., 2019 
всі труднощі воєнного, післявоєнного часу, відбудовували «народне господарство», продовжили боротися 3 кремлівським режимом у складі ОУН і УПА після вигнання з України гітлерівців.

Вказана книга засвідчує також особливу увагу до експонатів $\mathrm{i}$ документальних матеріалів, які зберігаються в НМІУ ДСВ, спрямовуючи увагу істориків на використання у своїх роботах музейних збірок, що, на жаль, залишається досить малопоширеним явищем. Проте, саме у фондах музеїв можна виявити особливо цікаві матеріали, прямі релікти минулого, які здатні розвинути важливі сюжети досліджень.

Мета видання, як зазначено у вступній частині «До читача», така: «Не лише продемонструвати багатогранність і строкатість подій Другої світової війни на українських землях шляхом висвітлення ії окремих маркерних проблем, а й розкрити за допомогою автентичних музейних предметів складні та болючі реалії, що ставили людину на межу безжалісного воєнного буття» (с. 7-8).

Варто також позитивно оцінити той факт, що автори й упорядники завдяки добре продуманій композиції структурних розділів видання, які відображають різні грані війни («Синдром війни», «Без вибору», «Окупанти», «Виживання», «Голокост», «Жінки», «Діти», «Руїна», «(Не)закінчена війна»), зробили акцент на різнорідному джерельному та предметному матеріалі, який зберігається у фондах НМІУ ДСВ. Завдяки цьому «здійснено спробу рельєфно, без упереджених висновків і нав'язливих штампів окреслити ті грані воєнного лихоліття, що дадуть можливість простежити різновимірний характер Другої світової війни та іiі глибокий слід у пам'яті народу» (с. 8). Разом із тим, розділи сформовані таким чином, що кожна їх сторінка відкриває окрему грань війни, відображаючи різні аспекти розглянутого питання. У книзі здійснений також паралельний переклад на англійську мову тез i підписів до фото, засвідчуючи, що видання розраховане також на іноземного читача. Крім того, кожний експонат і документ містить свою фондову легенду зберігання у НМІУДСВ. У кінці видання розміщені іменний і предметний покажчики.

Перший розділ «Синдром війни» дає можливість простежити через призму особистісного підходу, яким чином війна руйнувала життя цілих родин і впливала на долі людей. Вплив війни визначався тим, що частина червоноармійців та військових поверталися 3 
неї інвалідами, інші, переживши значні моральні потрясіння, вже у мирний час ставали недисциплінованими та займалися пияцтвом (c. 20-21).

Значна увага приділена смертності на війні. Зокрема, у результаті того, що у ЧА вона була високою, у післявоєнний час з'явилася велика кількість сімей без чоловіків (були випадки, що майже цілі села (с. 22)). Відображено також і те, що, коли становище на фронті було безвихідним, солдати, розуміючи це, власноруч писали свої «похоронки» (с. 25), у той же час для десятків тисяч моряків море стало братською могилою. У сповіщеннях про загибель останніх коротко зазначалося: «Тіло передане морю» (с. 31).

У розділі «Без вибору», завдяки музейним артефактам, показаний вибір, який мали ті, хто під час Другої світової війни був мобілізований у радянську, польську, німецьку чи угорську армію, перебував серед оточенців, «штрафників» $\mathrm{i}$ «чорносвитників». Цей розділ дає можливість простежити, що несла в собі військова повинність і який вибір мали кадрові військові чи мобілізовані новобранці, потрапивши на фронт. У вступі до розділу автори вірно відзначили, що в українців не питали, в яких арміях служити, а відтак у ситуації «без вибору» суттєвим міг бути лише фактор везіння (с. 35). У той же час відзначено, що не мали вибору i поляки, які, проживаючи у Західній Україні, потрапляли під мобілізацію до лав ЧА (с. 47). Крім того, на прикладі історії родини Дрімайлів-Крокосів яскраво віддзеркалено, яким чином війна на території бездержавного народу, який перебував у складі інших країн, розводила по різні боки близьких людей (с. 49).

Наступний розділ «Окупанти» відправляє читача та оглядача книги у світ жорстокості, який творив нацистський окупаційний режим. Автори-упорядники зазначили, що окупанти в Україні поводилися значно нахабніше, ніж у інших країнах. Як результат, їх жертвою став кожний шостий іiі житель. Зважаючи на цю цифру, погоджуємося, що окупованим людям довелося жити у час, коли життя було знецінене як таке (с. 51).

Разом із тим у виданні відображена думка, що окупантом українських земель був також Радянський Союз (с. 53, 54, 61). Наповнення цього розділу доводить нестерпність окупаційного режиму, який широко розгорнув терор та економічне пограбування України, вербував і вивозив трудові ресурси. У книзі висвітлені окремі факти культурного життя та спорту, що мали місце у період 
окупації (с. 74-77). Варто відзначити також окрему неточність на c. 80, де у підписі до фото щоденника А. Згурського - мешканця с. Борщів, не вказано, що перелічені села були спалені нацистами на Радомишльщині «немов за те, що там були партизани», як це зазначено на одному із зображень сторінок наративного джерела.

Розділ «Виживання» відкриває завісу над питаннями, що відображають складнощі, 3 якими довелося зіткнутися цивільним мешканцям у результаті та під час нацистської окупації (евакуація, проблеми 3 продовольчими ресурсами, розруха). Зокрема, населенню, щоб вижити, доводилося працювати в окупанта, вдаючись до «економічного колабораціонізму». Своєю чергою, чоловіки, щоб забезпечити свої сім'ї, досить часто ставали військовими окупаційної армії, службовцями поліції тощо. Варто погодитися 3 авторами, що колабораціонізм українців - одна 3 трагедій Другої світової війни, яка розвела останніх по різні боки, замість того, щоб об'єднати в боротьбі проти ворогів української державності (с. 85). Красномовною є тут листівка «Попередження» Комітету сприяння червоним партизанам, що за їх видачу поліції чи жандармам винні будуть покарані смертю за законами СРСР (с. 95).

Автори за допомогою музейних матеріалів висвітлили проблему пропагандистської кампанії гітлерівців, спрямовану на вербування молоді до Райху та їх важких умов життя там (с. 100-103), а також показано тяжку долю радянських військовополонених, які у роки війни фактично опинилися поза законом як для нацистського, так і для більшовицького режимів (с. 104-105).

У виданні окремим розділом розглянуто також трагедію «Голокосту» на території України, в якому, завдяки окремим документам і музейним експонатам, віддзеркалено його людиноненависницький сюжет і расову політику гітлерівців (с. 108-119).

Відображає розвиток сучасної історіографічної думки розділ «Жінки», де завдяки індивідуальним документам, фото та особистим речам висвітлено складність і нелінійність жіночого досвіду війни, що тривалий час розглядався як другорядний, допоміжний або винятковий. У доступній формі показано як радянським жінкам доводилося замінювати на робочих місцях чоловіків, воювати у ЧА, боротися 3 окупантами у складі партизанських загонів, ставати примусовими робітниками в Німеччині. Не залишилась поза увагою також трагічна доля жінок в українському повстанському pyci (c. 139). 
Важливий із погляду повноти зображення граней війни розділ «Діти». Буремні події Другої світової змусили їх бути складовою руху Опору, боротися за своє майбутнє, вступаючи в УПА, радянські партизани та навіть на флот і у ЧА. Воєнний і післявоєнний періоди зверталися до дорослості дітей, яким доводилося завчасно вступати у серйозне життя та жертвувати дитинством. Примітним у даному випадку є факт, як 12-річний Я. Дацюк у 1941 р. потрапив до ЧА, де став розвідником, чотири рази отримував поранення та лише у 1944 р. через непризовий вік був направлений у тил (с. 153). Наслідки війни для дітей були гіркими, адже вона позбавляла їх дитинства, багато з них ставали сиротами й інвалідами.

У розділі «Руїна» відображені руйнівні наслідки Другої світової війни, які не обійшли ії учасників, незважаючи на їх ідеологічну та політичну прихильність, вплинувши на життя як червоноармійця, так і українського повстанця й підпільника. Вигнання нацистів, окрім довгоочікуваного миру не принесло втіхи, оскільки післявоєнна руїна лише підтверджувала жорстокість війни, а повернення iз німецького полону чи концентраційних таборів породжували серйозну перевірку та пильний нагляд держорганів. Відлуння війни засвідчило у післявоєнний час значні проблеми з продовольством. Зокрема, товари цивільне населення отримувало за картками, а звинувачених i засуджених за крадіжку зерна відправляли до виправно-трудових таборів, з яких не всі повертались (с. 183); за невихід на роботу до мобілізованих на збирання врожаю могла застосовуватися відповідальність за законом воєнного часу (с. 185).

В останньому розділі видання «(Не)закінчена війна» відображені долі людей, які підтримували ОУН і УПА та боролися проти більшовиків у післявоєнний період. Окрім даної проблеми на основі особистих речей і фото показані репресії радянського режиму проти Греко-католицької церкви, трансфер населення, який відбувався між Польщею та УРСР у 1944-1946 років. Варто відзначити, що у цьому розділі розміщені також фото із сучасної російськоукраїнської неоголошеної війни на сході України, яка триває вже понад п'ять років, що демонструє прагнення авторів провести паралелі з останньою та «незакінченим етапом» Другої світової.

Позитивно оцінюючи високий рівень та унікальність рецензованого видання, хочемо висловити кілька зауважень. На нашу думку, варто було окремим розділом представити комуністичне 
підпілля, радянський партизанський та український повстанськопідпільні рухи, оскільки вони були помітною сторінкою Другої світової війни на терені України. Їх діяльність вплинула на життя як цивільного населення, котре опинилося в німецькій окупації, так і на ситуацію у ряді регіонів України, де діяли останні. Окрім того, через більшовицьке та націоналістичне підпілля, партизанські й упівські загони пройшло не менше 350 тис. осіб у 1941-1944 pp. (Патриляк, 2012: 234-236).

Зазначимо також, що у книзі є окремі неточності. Зокрема, на с. 177 зазначені недостовірні дані, що льотчик Г. Волошин під час боїв у Східній Пруссії здійснив повітряний таран, у результаті якого ніби не загинув, а вижив (хоча тіло не було знайдено), залишившись без рук і ніг, слуху та здатності розмовляти. Він ніби у такому безмовному стані чверть століття прожив як «невідомий солдат» у спецінтернаті для інвалідів на о. Валаам. Однак кременчуцький краєзнавець В. Івушкін, здійснивши ретельне розслідування, встановив, що насправді Г. Волошин все ж таки загинув 16 січня 1945 р., а вся подальша історія про ніби те, що останній вижив, містифікація (Ивушкин, 2019). У той же час у книзі вперше опубліковано сповіщення про загибель Г. Волошина, де автори документу помилилися, зазначивши невірне ім'я та прізвище його матері (c. 177). (Правильно мало бути так: Волошина Марія Кононівна).

Швидше за все, при підготовці тези до публікації цього документу автори-упорядники використовували статті російських або киргизстанських друкованих та Інтернет видань, які «роздули» історію-вигадку про льотчика Г. Волошина. (Як пояснював В. Івушкін, швидше за все, винний у тому, що російськомовні ЗМІ широко розповсюдили дану історію - син Г. А. Волошина, червоноармійця (призивався на війну з Киргизстану), який зник безвісті у 1942 р. Можливо, щоб отримати собі преференції за рахунок зовсім іншої людини, яка у роки війни здійснила героїчний вчинок і мала однакове прізвище, ім'я та по батькові, він у 1994 р. поставив пам'ятник батьку на чужій могилі на о. Валлам. Таким чином, син Волошина-червоноармійця перетворився у нащадка льотчика, що таранив німецький літак. Він також присвоїв йому звання Героя Радянського Союзу, яке надане йому не було (тому в багатьох публіцистичних статтях зазначається, що пілот Г.А. Волошин ніби отримав його посмертно!) (Особистий архів 
А.Ю. Сухих). Звичайно, що варто було перевірити ці дані на достовірність за допомогою документів, хоча це досить клопітка робота, як доводить дослідження В. Івушкіна.

У цілому варто відзначити, що рецензоване видання є унікальним у своєму роді та підготовлене на високому рівні. Структура книги підтверджує, що вона має науково-популярний формат i розрахована на широкого читача, хоч може бути особливо корисною для фахових істориків, оскільки у ній уміщені досить багато маловідомих фактів, які висвітлюють особисті сторінки гірких i щасливих історій людей в умовах безжалісного воєнного буття. Завдяки останнім відображена багатогранність і строкатість Другої світової війни на території України, складні реалії останньої, що ставила людину на межу виживання.

\section{Використані посилання}

Ивушкин В. Э. Летчик мл. лейтенант Волошин Григорий Андреевич (когда правда превращается в ложь), [online] Доступно: <http://gorod-kremenchug.pl.ua/ Kremenchug_1941-1943/Voloshin/ Voloshin.html> [Дата звернення 01 вересня 2019]

Лист від В. Івушкіна (28.08.2019 р.). Особистий архів А. Ю. Сухих.

Патриляк І. К., 2012. «Встань і борись! Слухай і вір...»: українське націоналістичне підпілля та повстанський рух (1939-1960рр.), Львів, Часопис, 592 с. 